\title{
System Architecture for Virtual Team Campus on Cloud to Support Internal Quality Assurance of Rajamangala University of Technology
}

\author{
https://doi.org/10.3991/ijoe.v15i07.10414 \\ Varit Kankaew ( $\left.{ }^{\bowtie}\right)$, Panita Wannapiroon \\ King Mongkut's University of Technology North Bangkok, Bangkok, Thailand \\ varit.kermutsb.ac.th
}

\begin{abstract}
This research has a purpose to study and design the system architecture for virtual team campus on Cloud to support the internal quality assurance of Rajamangala University of Technology. The research was divided into two steps as follows: 1) system architecture design and 2) system architecture assessment. The samples of this research consisted of 10 experts involved in internal quality assurance and information and communication technology chosen by using a specific selection method. The assessment form was used as a research instrument to assess the system architecture for virtual team campus on Cloud to support internal quality assurance work of Rajamangala University of Technology. The statistics used in this study were Arithmetic Mean and Standard Deviation. The results of the research showed that the Cloud system architecture processing model in the form of software services which demonstrated the systems and modules that worked together under the context of Rajamangala University in internal quality assurance work in this research consisted of 2 main systems, 11 sub-modules that each system and module was important for system development. The assessment of the system architecture from experts found that the system architecture designed by the researcher was at very good level which showed that the architecture that the researcher has designed can be used to develop the system of virtual team campus on Cloud to support the internal quality assurance of Rajamangala University of Technology.
\end{abstract}

Keywords-Virtual team, cloud computing, internal quality assurance, system architure

\section{Introduction}

Education is one of the fundamental factors for the development. Higher education is considered as an important part of the country's economic and social development. For this reason, the government needs to improve higher education and maintain a high level of education. [1,2] The concepts of quality and quality assurance are important and more popular. Therefore, higher education quality assurance is important. [3] Higher quality assurance therefore encourages customers, build confidence for partners, meet the needs and the expectation of receiving higher education providers 
[4] The development of Thai educational standards and quality assurance currently requires the quality assurance system for education to improve the quality and educational standards comprising internal quality assurance systems and external quality assurance systems by considering internal quality assurance as a mission of the educational administration process. Educational institutions therefore must develop systems and mechanisms for quality assurance to be used in pursuing, monitoring and evaluating the operation to be in accordance with the policy plan, goals and quality standards set by the educational institutions or agencies continuously in order for the stakeholders to be satisfied and create confidence in the quality of graduates which the educational quality assurance system within the tertiary level consists of insurance, faculty level in curriculum level, faculty level and institutional level [5-7] In order for the quality assurance of education to be useful, there should be a guideline for organizing the internal quality assurance process according to the quality cycle consisting of 4 steps:

- Planning (Plan)

- Operating and data collecting (Do)

- Quality assessment (Check)

- Suggesting for improvement (Action) $[5,8]$

The virtual team is a method used by organization uses to help the staffs work together, even though they are in different location and times which has limitations in having to come face to face. The virtual team will work together using telecommunication and communication technology to achieve common goals. If being managed effectively, the virtual team will bring the benefits of teamwork and have the potential to create superiority, working as a team that must work face-to-face.[9-16] that the communication technology is an important part of the virtual team to work. [17] Cloud is a technology that allows users to use software and applications from online environments anytime that users can store data at a remote location and can be accessed from an internet-connected device. Virtual teams can store all the information in one place. The chances of duplication of documents on other computers will be reduced, making sure that the latest version of the document is used [18-26].

From the above information, the researchers designed the system architecture for virtual team campus on Cloud to support the internal quality assurance work of Rajamangala University of Technology according to the administrative context of Rajamangala University of Technology comprising many educational centers in order to be able to work together as a team according to the internal quality assurance system and mechanism.

\section{Research Objectives}

The purposes of this study were:

- To design the system architecture for virtual team campus on Cloud to support internal quality assurance work of Rajamangala University of Technology. 
- To assess the system architecture for virtual team campus on Cloud to support internal quality assurance work of Rajamangala University of Technology.

\section{$3 \quad$ Research Methodology}

This research is a research and development (R\&D) which was divided into 2 steps as follows.

\subsection{The first steps}

Designed the system architecture for virtual team campus on Cloud to support internal quality assurance of Rajamangala University of Technology which comprised following details:

System architecture design used data obtained from research, synthesis analysis including related researches. The process of the system was in accordance with the internal quality assurance process according to the quality cycle (PDCA) [5] and the instrument used in the team as from the synthesis as shown in Table 1.

Table 1. The tools to be used in virtual team

\begin{tabular}{|c|c|c|c|c|c|c|c|}
\hline Tools & $\begin{array}{l}\text { Becker, } \\
\text { J. et al. } \\
\text { (1999) }\end{array}$ & $\begin{array}{c}\text { Duarte, D . } \\
\text { L. \& } \\
\text { Snyder, N . } \\
\text { T . (2001) }\end{array}$ & $\begin{array}{c}\text { Sivunen, } \\
\text { A., \& } \\
\text { Valo, A. } \\
\text { (2006) }\end{array}$ & $\begin{array}{c}\text { Thissen, } \\
\text { M.R. et al. } \\
(2007)\end{array}$ & $\begin{array}{c}\text { Tur- } \\
\text { ban, E. } \\
\text { et al. } \\
(2011)\end{array}$ & \begin{tabular}{|c|} 
O'Ke \\
efe, \\
M., \& \\
Chen, \\
E. T. \\
(2011 \\
) \\
\end{tabular} & \begin{tabular}{|c|} 
อนัน ต์ \\
เกิดดำ \\
$(\mathbf{2 5 5 1}$ \\
)
\end{tabular} \\
\hline $\begin{array}{l}\text { Desktop and real-time data confer- } \\
\text { encing }\end{array}$ & & $\checkmark$ & & & & & $\checkmark$ \\
\hline Electronic meeting systems & & $\checkmark$ & & & & & \\
\hline Video conferencing & $\checkmark$ & $\checkmark$ & $\checkmark$ & & & & $\checkmark$ \\
\hline Audio conferencing & $\checkmark$ & $\checkmark$ & $\checkmark$ & & & & $\checkmark$ \\
\hline E-mail & $\checkmark$ & $\checkmark$ & $\checkmark$ & $\checkmark$ & & & $\checkmark$ \\
\hline Group calendars and schedules & $\checkmark$ & $\checkmark$ & & & & & \\
\hline Bulletin boards and Web pages & & $\checkmark$ & & & & & \\
\hline $\begin{array}{l}\text { Non-real-time database sharing and } \\
\text { conferencing }\end{array}$ & & $\checkmark$ & & & & & \\
\hline Workflow applications & & $\checkmark$ & & & & & \\
\hline Instant Messaging and Chat & $\checkmark$ & & $\checkmark$ & $\checkmark$ & $\checkmark$ & $\checkmark$ & $\checkmark$ \\
\hline Groupware /Shared Services & & & & $\checkmark$ & & & \\
\hline Web Conferencing & $\checkmark$ & & & $\checkmark$ & & $\checkmark$ & $\checkmark$ \\
\hline File Transfer & & & & $\checkmark$ & & & \\
\hline Telephone & $\checkmark$ & & & $\checkmark$ & & & $\checkmark$ \\
\hline Wikis & & & & & $\checkmark$ & $\checkmark$ & \\
\hline Forums & $\checkmark$ & & $\checkmark$ & & $\checkmark$ & $\checkmark$ & \\
\hline Blogs & & & & & $\checkmark$ & $\checkmark$ & \\
\hline Social Networking Sites & & & & & $\checkmark$ & $\checkmark$ & \\
\hline
\end{tabular}




\begin{tabular}{|c|c|c|c|c|c|c|c|}
\hline Tools & $\begin{array}{c}\text { Becker, } \\
\text { J. et al. } \\
\text { (1999) }\end{array}$ & $\begin{array}{c}\text { Duarte, D . } \\
\text { L. \& } \\
\text { Snyder, N . } \\
\text { T.(2001) }\end{array}$ & $\begin{array}{c}\text { Sivunen, } \\
\text { A., \& } \\
\text { Valo, A. } \\
\text { (2006) }\end{array}$ & $\begin{array}{c}\text { Thissen, } \\
\text { M.R. et al. } \\
(2007)\end{array}$ & $\begin{array}{c}\text { Tur- } \\
\text { ban, E. } \\
\text { et al. } \\
(2011)\end{array}$ & \begin{tabular}{|c|} 
O'Ke \\
efe, \\
M., \& \\
Chen, \\
E. T. \\
$\left(\begin{array}{c}2011 \\
)\end{array}\right.$ \\
\end{tabular} & $\begin{array}{c}\text { อนัน ต์ } \\
\text { เกิดดำ } \\
\left(\begin{array}{c}2551 \\
)\end{array}\right.\end{array}$ \\
\hline Cloud & & & & & & $\checkmark$ & \\
\hline $\begin{array}{l}\text { Document Sharing and Collabora- } \\
\text { tion }\end{array}$ & & & & & & $\checkmark$ & \\
\hline File Sharing & & & & & & & $\checkmark$ \\
\hline $\begin{array}{l}\text { Collaborative Presentation Soft- } \\
\text { ware }\end{array}$ & $\checkmark$ & & & & & & \\
\hline Discussion Databases & $\checkmark$ & & & & & & \\
\hline Document Management Software & $\checkmark$ & & & & & & \\
\hline Electronic Document Management & & & & & & & $\checkmark$ \\
\hline Electronic White boarding & $\checkmark$ & & & & & & \\
\hline Group Scheduling and Calendaring & $\checkmark$ & & & & & & \\
\hline Knowledge Management systems & & & & & & & $\checkmark$ \\
\hline One-way Bulletin Boards & $\checkmark$ & & & & & & \\
\hline Project Management Software & $\checkmark$ & & & & & & \\
\hline Work Flow Management Systems & $\checkmark$ & & & & & & \\
\hline Discussion forums & $\checkmark$ & & & & & & \\
\hline
\end{tabular}

From Table 1, it showed that the researchers grouped the tools with similar properties and synthesized the tools to be used as a virtual team work in the internal quality assurance work and presents the tools from the synthesizer to the experts for interviewing and made corrections according to the advice of experts. The resulted system component comprised

- Internal Quality Assurance Workflow System which comprised Planning Module, Doing Module, Checking Module, Acting Module and Report Module

- Information Support System which comprised Knowledge Management Module, File Sharing Module and Document Management Module

- Communication Support System which comprised Instant Messaging Module, Web Conferencing Module and Electronic Mail Module.

As a sequence, the researchers created a questionnaire for samples who were involved in the internal quality assurance for the analysis of confirmed components of the system. The results of the analysis indicated that the system components that the researchers synthesized were at a good level. The researcher then applied the system components to design the team system architecture as a Cloud-based campus to support the internal quality assurance work of Rajamangala University of Technology.

The system architecture design was divided into 7 parts as follows:

1. Admins: The people who managed the basic information, such as system user information, agency information, etc.

2. Virtual Team: Teams that worked together in ensuring the quality of internal education by using a system divided into 3 teams, consisting of 
(a) Curriculum Team, which worked together in the quality assurance of education in the curriculum level

(b) Faculty Team, which worked together in the quality assurance of education in the faculty level

(c) Institution Team, which worked together in the quality assurance of education in the institution level. All 3 teams worked together within the team and between teams which team members may be on the campus or the center of the same or different study areas by working on internal quality assurance through a developed system

3. IQA Workflow System (IQA WS) which consisted of the following modules

(a) Planning Module (PM): A module used for work planning of internal quality assurance team in the curriculum level, faculty level and institution level.

(b) Doing Module (DM): A module used for operating, data collecting and recording of internal quality assurance result in the curriculum level, faculty level and institution level.

(c) Checking Module (CM): A module used for recording the results of educational quality assessment in the curriculum level, faculty level and institutional level.

(d) Acting Module (AM): A module used for recording guidelines for improvement of educational quality assurance in the curriculum level, faculty level and institutional level to be used as guidelines in the next academic year.

(e) Report Module (RM): A module used for issuing reports of information to be used in the operation of internal quality assurance in the curriculum level, faculty level and institution level.

4. Collaboration Support System (CSS) which consisted of the following 2 subsystems

(a) Information Support System (ISS) which comprised the following modules:

(i) Knowledge Management Module (KMM): A module used for exchanging opinions, knowledge, information between the quality assurance teams in curriculum level, faculty level and institution level.

(ii) File Sharing Module (FSM): A module used for file sharing and using files together between team members and between the quality assurance teams in curriculum level, faculty level and institution level

(iii) Document Management Module (DMM): A module used for managing documents that were shared between team members and between quality assurance teams in curriculum level, faculty level and institution level

(b) Communication Support System (CSS) which comprised the following modules:

(i) Instant Messaging Module (IMM): A module for instant text conversation between team members and between course quality assurance teams in curriculum level, faculty level and institution level.

(ii) Web Conferencing Module (WCM): A module used for chatting or conferencing over the internet between team members and between the quality assurance teams in curriculum level, faculty level and institution level.

(iii) Electronic Mail Module (EMM): A module used for sending email to find each other between team members and between the course quality assur- 
ance teams in curriculum level, faculty level, institutional level and involved people.

5. System data storage: The system stored data in the form of database (IQA Database) and store various documents on Cloud (Cloud Storage).

6. Executives: People who involved in the audit of work requesting an operation report from the system. The executives were divided into 3 groups:

(a) Executive Curriculum

(b) Executive Faculty

(c) Executive Institution

7. Cloud Service: the application of Cloud-based processing for sharing resources over the internet to work as a virtual team that will be an important part in developing a team system campus on Cloud in order to support the internal quality assurance work of Rajamangala University of Technology with group processing software called Cloud. Cloud was the core of the system to support the virtual team campus system to work efficiently. As a result, the teams can work together as a team through technology by working with the system using Cloud computing services. (Software-as-aService)

The system architecture is shown as Fig. 1:

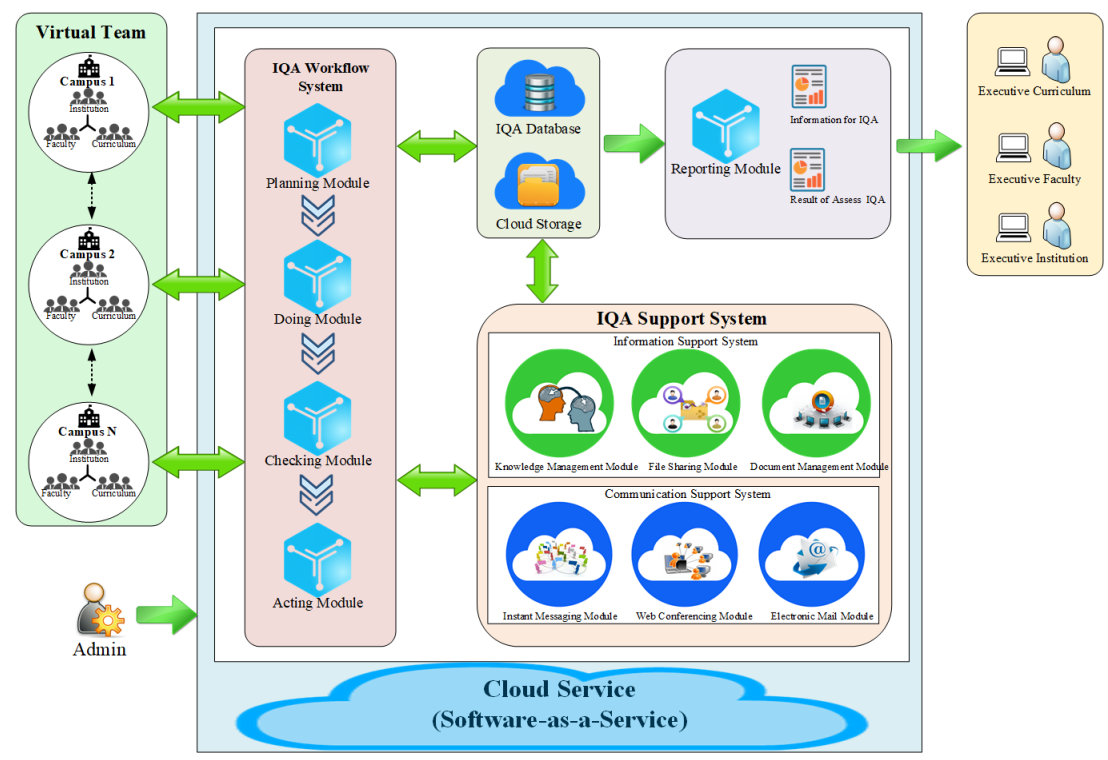

Fig. 1. The System Architecture of Virtual Team Campus on Cloud to Support Internal Quality Assurance of Rajamangala University of Technology 


\subsection{The second steps}

Assessed the system architecture for virtual team campus on Cloud to support the internal quality assurance of Rajamangala University of Technology which consisted of the following steps:

- Presented the designed system architecture to 10 experts involved in internal quality assurance and information and communication technology to assess then the researchers improved the system architecture according to the advice of experts.

- Analyzed the assessment of the system architecture by using the average (x) and standard deviation. (S.D.) The assessment was designed as a 5-level rating survey by Likert.

\section{$4 \quad$ Research Results}

The assessment of the system architecture designed by the researchers as advised by from experts can be summarized as follows:

Table 2. The assessment result of system architecture

\begin{tabular}{|c|c|c|c|}
\hline List of assessment & $\overline{\boldsymbol{x}}$ & S.D. & Result \\
\hline 1. The users involving in the system & 4.70 & 0.47 & Very good \\
\hline 1.1Admins & 4.60 & 0.52 & Very good \\
\hline 1.2 Virtual Teams & 4.80 & 0.42 & Very good \\
\hline 1.3Executives & 4.70 & 0.48 & Very good \\
\hline $\begin{array}{l}\text { 2. System components that worked together as a virtual team in the } \\
\text { internal quality assurance work }\end{array}$ & 4.60 & 0.59 & Very good \\
\hline 2.1 Internal Quality Assurance Workflow System :IQA WS & 4.74 & 0.50 & Very good \\
\hline 2.1.1Planning Module :PM & 4.70 & 0.48 & Very good \\
\hline 2.1.2Doing Module :DM & 4.80 & 0.42 & Very good \\
\hline 2.1.3Checking Module :CM & 4.70 & 0.48 & Very good \\
\hline 2.1.4Acting Module :AM & 4.80 & 0.63 & Very good \\
\hline 2.1.5Reporting Module :RM & 4.70 & 0.48 & Very good \\
\hline 2.2 Collaboration Support System : CSS & 4.50 & 0.64 & Very good \\
\hline 2.21 Information Support System :ISS & 4.53 & 0.65 & Very good \\
\hline 2.2.11 Knowledge Management Module :KMM & 4.60 & 0.52 & Very good \\
\hline 2.21 2.File Sharing Module :FSM & 4.30 & 0.95 & Good \\
\hline 2.21 3.Document Management Module :DMM & 4.70 & 0.48 & Very good \\
\hline .22 .2 Communication Support System :CSS & 4.47 & 0.64 & Good \\
\hline 2.2.2 1.Instant Messaging Module :IMM & 4.40 & 0.70 & Good \\
\hline 22.2 2.Web Conferencing Module: WCM & 4.60 & 0.52 & Very good \\
\hline 22.2 3.Electronic Mail Module: EMM & 4.40 & 0.70 & Good \\
\hline 3.The operation principles of system architecture & 4.53 & 0.62 & Very good \\
\hline $\begin{array}{c}.31 \text { The operation of the system is in accordance with the internal } \\
\text { quality assurance process. }\end{array}$ & 4.60 & 0.70 & Very good \\
\hline $\begin{array}{l}3.2 \text { The appropriateness of each sub-system work relationship in working } \\
\text { together as a virtual team. }\end{array}$ & 4.40 & 0.84 & Good \\
\hline 3.3 The operation of the system helps to work together as a team between & 4.60 & 0.52 & Very good \\
\hline
\end{tabular}




\begin{tabular}{|l|c|c|c|}
\hline campuses. & & & \\
\hline $\begin{array}{l}\text { 3.4 The appropriateness of Cloud service processing systems (Cloud } \\
\text { Service) }\end{array}$ & 4.60 & 0.52 & Very good \\
\hline $\begin{array}{l}.35 \text { The operation principle of the system through Cloud computing in the } \\
\text { form of software services (Software-as-a-Service) }\end{array}$ & 4.30 & 0.67 & Good \\
\hline .36 Appropriate storage system (Database, Cloud Storage) & 4.70 & 0.48 & Very good \\
\hline Total average assessment results & 4.60 & 0.58 & Very good \\
\hline
\end{tabular}

From Table 2, the assessment of the system architecture for virtual team campus on Cloud to support the internal quality assurance work of Rajamangala University of Technology from experts found that the assessment results were at the most appropriate level from the assessment results in 3 aspects, namely, the first group of users related to the system which found that the average level of suitability was at the highest level; The second aspect, the composition of the system virtual team campus on Cloud support the internal quality assurance of Rajamangala University of Technology found that the average level of suitability was at the highest level and the third aspect, the working principle of system architecture, found that the average level of suitability was at the highest level.

From the assessment of the system architecture, it was known that in terms of user groups related to the system was at the most appropriate level. This showed that the operation the system consists of user groups, ie admins, virtual teams and executives that will work together as a virtual team in the work of insuring the quality of education by working with the system, work procedures, quality assurance, internal education and internal quality assurance support systems to achieve the goal of internal quality assurance work; to obtain information in support of internal quality assurance; to reduce the problem of places, time and distance to travel to be able to work together.

\section{Conclusion}

The system architecture for virtual team campus on Cloud to support internal quality assurance work of Rajamangala University of Technology was designed to create a collaborative team environment by using information and communication technology according to the administration context of Rajamangala University of Technology, which has managed many educational space centers in order to be able to work together according to the internal quality assurance system and mechanism. The system was designed by using quality circuits (PDCA) [5]. The researchers found that the system architecture that was designed with the use of information and communication technology in accordance with the working principle of the system through cloudbased processing in the form of software services to work together as a virtual team. System architecture consisted of user groups, ie admins, virtual teams and executives which will work together as a virtual team to work within the quality assurance work by working with the system of work procedures, internal quality assurance which consisted of 5 modules including: 
- Planning Module

- Doing Module

- Checking Module

- Acting Module

- Reporting Module

Together with team collaboration support system for internal quality assurance that included Information Support System which consisted of 3 modules, namely:

- Knowledge Management Module

- File Sharing Module

- Document Management Module

Communication Support System, which consisted of 3 modules, namely:

- Instant Messaging Module

- Web Conferencing Module

- Electronic Mail Module

Each of the aforementioned modules played an important role in system development in bringing support to work together as a team in internal quality assurance work which each module was consistent with the researches of various authors [27-34]. This showed that the systems and modules that the researcher has designed can work together to achieve the goals of internal quality assurance work in order to obtain information for supporting internal quality assurance work and reducing the problem of places, time and distance to work together.

The system architecture model designed by researchers focused on the approach that educational institutions can use to develop the system to support team collaboration in the organization even in different locations by interacting through information and communication technology systems to achieve common goals in work together with information sharing, educational exchange and cooperative work improvement.

\section{Acknowledgement}

This research received a partial thesis research grant for graduate students from the Graduate College at King Mongkut's University of Technology North Bangkok. The researchers would like to express sincere gratitude to the Vacation Education Technology Research Center of the Science and Technology Research Institute, King Mongkut's University of Technology North Bangkok, for supporting this research.

\section{$7 \quad$ References}

[1] Adamu, A. Y., \& Addamu, A. M. (2012). Quality Assurance in Ethiopian Higher Education: Procedures and Practices. Procedia - Social and Behavioral Sciences, 69, 838-846. https://doi.org/10.1016/j.sbspro.2012.12.006 
[2] Alshayea, A. (2012). Improvement of the Quality Assurance in Saudi Higher Education. Procedia - Social and Behavioral Sciences, 47, 2234-2236. https://doi.org/10.1016/j.sbspro.2012.06.978

[3] Keçetep, İ., \& Özkan, İ. (2014). Quality Assurance In The European Higher Education Area. Procedia - Social and Behavioral Sciences, 69, 660-664. https://doi.org/10.1016/j.sbspro.2014.05.115

[4] Todorescu, L.-L., Greculescu, A., \& Lampă, I. (2014). Implementation of Quality Assurance in Romanian Technical Higher Education - Objective Set by the Bologna Process. Procedia - Social and Behavioral Sciences, 122, 443-447. https://doi.org/10.1016/j.sbspro.2014.01.1369

[5] Office of the Higher Education Commission. (2014). Manual for the Internal Quality Assurance for Higher Education Institutions 2014.

[6] Quality Assurance Committee, Silpakorn University. (2013). Development of Internal Education Quality Assurance: A Case Study of Academic Supporting Agencies, Silpakorn University.

Daromes, F. E., \& Ng, S. (2015). Embedding Core Value into the Internal Quality Assurance Systems in Higher Education. Procedia - Social and Behavioral Sciences, 211, 660664. https://doi.org/10.1016/j.sbspro.2015.11.096

Belash, O., Popov, M., Ryzhov, N., Ryaskov, Y., Shaposhnikov, S., \& Shestopalov, M. (2015). Research on University Education Quality Assurance: Methodology and Results of Stakeholders' Satisfaction Monitoring. Procedia - Social and Behavioral Sciences, 214, 344-358. https://doi.org/10.1016/j.sbspro.2015.11.658

[7] Bell, B. S., \& Kozlowski, S. W. J. (2002). A Typology of Virtual Teams. Group \& Organization Management, 27(1), 14-49. https://doi.org/10.1177/1059601102027001003

[8] Gatlin-Watts, R., \& Carson, M. (2007). A guide to global virtual teaming, Emerald Group Publishing Limited. Team Performance Management, 13, 47-52. https://doi.org/10.1108/13527590710736725

[9] Bhat, S. K., Pande, N., \& Ahuja, V. (2017). Virtual Team Effectiveness: An Empirical Study Using SEM. Procedia Computer Science, 122, 33-41.

https://doi.org/10.1016/j.procs.2017.11.338

Yoo, Y., \& Kanawattanachai, P. (2001). DEVELOPMENTS OF TRANSACTIVE MEMORY SYSTEMS AND COLLECTIVE MIND IN VIRTUAL TEAMS. The International Journal of Organizational Analysis, 9(2), 187-208. https://doi.org/10.1108/eb028933 Hoch, J. E., \& Dulebohn, J. H. (2017). Team personality composition, emergent leadership and shared leadership in virtual teams: A theoretical framework. Human Resource Management Review, 27(4), 678-693. https://doi.org/10.1016/j.hrmr.2016.12.012

Hoch, J. E., \& Kozlowski, S. W. J. (2014). Leading virtual teams: Hierarchical leadership, structural supports, and shared team leadership. Journal of Applied Psychology, 99(3), 390-403. https://doi.org/10.1037/a0030264

Ford, R. C., Piccolo, R. F., \& Ford, L. R. (2017). Strategies for building effective virtual teams: Trust is key. Business Horizons, 60(1), 25-34.

https://doi.org/10.1016/j.bushor.2016.08.009

[10] Lim, J. Y.-K. (2018). IT-enabled awareness and self-directed leadership behaviors in virtual teams. Information and Organization, 28(2), 71-88.

https://doi.org/10.1016/j.infoandorg.2018.02.001

Laitinen, K., \& Valo, M. (2018). Meanings of communication technology in virtual team meetings: Framing technology-related interaction. International Journal of HumanComputer Studies, 111, 12-22. https://doi.org/10.1016/j.ijhcs.2017.10.012 
[11] O'Keefe, M., \& Chen, E. T. (2011). The Impact of Emergent Web 2.0 on Virtual Teams. Communications of the IIMA, 11, 91-106

[12] Yaowong, A. (2013). The Data Information Storage and Usage on Cloud Computing Technology. Journal of Vocational and Technical Education, 3(6), 25-33. Hu, L., Zhao, J., Xu, G., Ding, Y., \& Chu, J. (2013). A Survey on Green Computing Based on Cloud Environment. International Journal of Online and Biomedical Engineering, 9(3), 27-33. https://doi.org/10.3991/ijoe.v9i3.2559

[13] Kamolchaipisit, K. (2013). Enterprise Resource Planning in Cloud Computing: Opportunities and Challenges. Journal of Vocational and Technical Education, 3(6), 25-33.

Shana, Z., \& Abulibdeh, E. (2017). Cloud Computing Issues for Higher Education: Theory of Acceptance Model. International Journal of Emerging Technologies in Learning, 12(11), 168-184. https://doi.org/10.3991/ijet.v12i11.7473

[14] Rodmunkong, T., \& Wannapiroon, P. (2013). The Design of Cloud ComputingManagement Information System Accordance with Thai Qualifications Frameworkfor Higher Education. International Journal of e-Education, e-Business, e-Management and e-Learning, 3, 214-218.

[15] Songsangyos, P., \& Nilsook, P. (2015). Big Data in the Cloud for Education Institutions. The Twelfth International Conference on eLearning for Knowledge-Based Society.

[16] Nookhong, J., \& Nilsook, P. (2017). System Architecture for Green University Resource Planning on Cloud Computing. International Journal of the Computer, the Internet and Management, 25, 68-75.

[17] El-Sofany, H. F. \& El-Seoud, S. A. (2019). Performance Analysis of an Effective Approach to Protect Cloud Systems against Application Layer Based Attacks. International Journal of Online and Biomedical Engineering, 15(3), 82-95. https://doi.org/10.3991/ijoe.v15i03.9931

[18] Duarte, D.L. \& Snyder, N.T.(2006). Mastering Virtual Teams. 3rd ed. San Francisco : Jossey-Bass.

[19] Sivunen, A., \& Valo, M. (2006). Team Leaders' Technology Choice in Virtual Teams. IEEE Transactions on Professional Communication, 49, 57-68. https://doi.org/10.1109/TPC.2006.870458

[20] Thissen, M. R., Page, J. M., Bharathi, M. C., \& Austin, T. L. (2007). Communication tools for distributed software development teams. Proceedings of the 2007 ACM SIGMIS CPR Conference on 2007 Computer Personnel Doctoral Consortium and Research Conference The Global Information Technology Workforce - SIGMIS-CPR '07. https://doi.org/10.1145/1235000.1235007

[21] Keefe, M. O. \& Chen, E.T. (2011). The Impact of Emergent Web 2.0 on Virtual Teams. Communications of the IIMA, 11, 91-106.

[22] Davidekova, M., \& Hvorecky, J. (2017). ICT Collaboration Tools for Virtual Teams in Terms of the SECI Model. International Journal of Engineering Pedagogy (iJEP), 7(1), 95. https://doi.org/10.3991/ijep.v7i1.6502

Turban, E., Liang, T.-P., \& Wu, S. P. J. (2010). A Framework for Adopting Collaboration 2.0 Tools for Virtual Group Decision Making. Group Decision and Negotiation, 20(2), 137-154. https://doi.org/10.1007/s10726-010-9215-5

[23] Becker, J., Ballentine, R., Lee, A., \& Townsley, C. (1999). Collaborative technology tools for virtual teaming. Proceedings of the Fifth Americas Conference on Information Systems, 5, 334-336.

[24] อนันต์ เกิดดำ. (2551). กระบวนการและเทคโนโลยีการบริหารทีมเสมือน. คอมพิวเตอร์และเทคโนโลชีชั้นสูง, $9,34-43$. 


\section{Authors}

Varit Kankaew is $\mathrm{PhD}$. Student division of Information and Communication Technology for Education, Faculty of Technical Education, King Mongkut's University of Technology North Bangkok (KMUTNB), Thailand, 10800 (email: varit.k@rmutsb.ac.th).

Panita Wannapiroon is an Associate Professor at Division of Information and Communication Technology of Education, Faculty of Technical Education, King Mongkut's University of Technology North Bangkok (KMUTNB), Thailand, 10800 (email: panitaw@kmutnb.ac.th).

Article submitted 2019-01-04. Resubmitted 2019-02-24. Final acceptance 2019-03-14. Final version published as submitted by the authors. 